\title{
Metabolic syndrome in patients with Schizophrenia: Relationship with socio-demographic \& clinical variables
}

\author{
Raghul Raj', Fiaz Ahmed Sattar', Kiran Kumar K ${ }^{3 *}$ \\ ${ }^{\mathbf{1}}$ Assistant Professor, ${ }^{2}$ Professor and Head, ${ }^{\mathbf{3}}$ Associate Professor, Dept. of Psychiatry, ${ }^{\mathbf{T}}$ The Oxford Medical College, Hospital \& Research \\ Centre, Bangalore, Karnataka, ${ }^{2,3}$ Vydehi Institute of Medical Sciences \& Research Centre, Bangalore, Karnataka, India
}

*Corresponding Author: Kiran Kumar K

Email: drkiran.psychiatry@gmail.com

\begin{abstract}
Background: Schizophrenia is an enduring severe mental illness with significant morbidity and early excess mortality. Metabolic syndrome (MetS) is a construct that aids psychiatrist to understand this constellation of risk factors leading to premature mortality. The current study was carried out with an aim to understand the association of metabolic syndrome in patients with schizophrenia and also to ascertain its relationship with socio-demographic \& clinical variables.

Materials and Methods: A cross sectional study was undertaken in patients suffering from Schizophrenia (F20) as per International Classification of Diseases (ICD-10. A total of one-hundred patients were selected by purposive random sampling after obtaining a written informed consent. A predesigned proforma was used to obtain the information regarding the sociodemographic variables, drug intake, anthropometric values and metabolic parameters. Metabolic syndrome was diagnosed as per the International Diabetes Federation- 2006 criteria. The data obtained was analysed using statistical package for social services (SPSS 20).

Results: The association of metabolic syndrome in schizophrenia in the current study was $42 \%$. The individual metabolic parameters were found to be higher in the MetS group than the non-MetS group $(\mathrm{p}=0.001)$. Majority of the schizophrenia patients with MetS were older $(59.5 \%$ vs $44.8 \% ; 31-50$ years of age) and females ( $52.4 \%$ vs $36.2 \%$; $=0.107)$ compared to those without MetS. Most of them were married ( $85.7 \%$ vs $56.9 \%$; $\mathrm{p}=0.006$ ), from urban areas ( $45.2 \%$ vs $19 \%$; $\mathrm{p}=0.005)$, had lower educational qualification ( $\mathrm{p}=0.01)$ in comparison to the non-MetS group. The MetS group had longer mean duration of schizophrenia (9.64 \pm 8.1 years vs 3.76 \pm 2.29 years), more hospitalizations $(66.7 \%$ vs $53.4 \% ; \mathrm{p}=0.02)$ and higher medical comorbidity (diabetes-7.1\% vs nil, hypertension-9.5\% vs $1.7 \%$ and hypothyroidism- $7.1 \%$ vs nil; $\mathrm{p}=0.006)$. With respect to psychotropic drugs usage; the use of Olanzapine (69\% vs $46.6 \%$; $\mathrm{p}=0.025)$, longer duration of treatment with Olanzapine $(26.31 \pm 33.9$ months vs $8.98 \pm 12.3$; $\mathrm{p}=0.001)$ and Amisulpride $(11.0 \pm 21.68$ months vs $3.48 \pm 9.9$; $\mathrm{p}=0.022)$ were significantly associated with MetS group than the group without MetS. On the contrary, the non-MetS group had more patients receiving risperidone (58.6\%) than the MetS group.

Conclusion: The study shows that the association of metabolic syndrome in schizophrenia patients is significantly in higher percentage and thereby underlines the importance of early detection and treatment of both the disorders simultaneously.
\end{abstract}

Keywords: Cardiovascular disorders, Metabolic syndrome, Schizophrenia, Type 2 diabetes mellitus.

\section{Introduction}

Schizophrenia is a debilitating mental illness that affects about one percent of the population in all cultures and it has varied and ominous symptoms that usually begins in late adolescence or early adulthood and is generally chronic. ${ }^{1}$ Patients suffering from schizophrenia in general have multiple medical comorbidities and available evidence suggest that patients with schizophrenia have about 15 to 20 years reduced life expectancy compared to the general population. ${ }^{2,3}$ An alarming trend noted indicates that this mortality gap associated with schizophrenia compared to the general population has widened in recent decades. ${ }^{4}$ The causes of death comprise a broad range of conditions, similar to the general population, but however death as a result of cardiovascular (CV) complications represents the leading aetiology of superfluous mortality in patients with schizophrenia., 5 To address this premature mortality in schizophrenia patients, the concept of Metabolic Syndrome (MetS) has gained importance in psychiatric literature. ${ }^{7}$

The Metabolic Syndrome (MetS, also known as syndrome X, syndrome of chronic cardiovascular disease and Reaven's syndrome) is a constellation of different conditions which are predictive of $\mathrm{CV}$ disease risk. $^{8}$ Metabolic syndrome is a cluster of risk factors which includes increased abdominal obesity, impaired glucose tolerance, dyslipidaemia and high blood pressure that causes increased cardiovascular disease and type 2 diabetes mellitus. ${ }^{8,9}$ All components of the MetS (with obesity holding a central role in its development) have been recognized as independent risk factors for cardiovascular disease. The MetS is helpful in screening and monitoring the risk of cardiovascular disease (CVD) and has therefore been studied extensively in relation to patients with schizophrenia in the past decades. ${ }^{10}$

The prevalence rates of MetS in schizophrenia varies from $11 \%$ to $69 \% .^{7}$ Understanding the precise reason for MetS in schizophrenia is an enigma. A number of elucidations like change in lifestyle and eating habits, increasing obesity epidemic, effect of psychotropic medications; particularly antipsychotics, alterations of the hypothalamic pituitary-adrenal axis (HPA) leading to hypercortisolemia, poor glycaemic control and possible variations in neuroanatomical architecture, particularly hippocampal volume have been proposed. . $^{2-10-12}$

Schizophrenia brings together a series of sociodemographic, clinical and metabolic parameters which are predictive of cardiovascular disease risk. The association between schizophrenia and the metabolic syndrome is emerging as a public health question of importance to both 
mental health and primary care practitioners. In order to address the above issue, the current study was carried out with an aim to evaluate the association of metabolic syndrome in patients with schizophrenia and to evaluate the relationship of metabolic syndrome with socio-demographic and clinical variables of patients with schizophrenia.

\section{Materials and Methods}

This is a cross-sectional descriptive study of patients with a diagnosis of Schizophrenia, as per International Classification of Diseases (ICD-10) classification of Mental and Behavioral disorders attending to the teaching hospital facility of Vydehi Institute of Medical Sciences and Research Centre, Bangalore. Ethical clearance was obtained from the Institutional ethics committee.

\section{Sample size}

In order to estimate with sufficient precision, we hypothesized that the prevalence of MetS to be $30 \%$. We calculated the sample size with a $99 \%$ confidence interval and of a $10 \%$ width. Based on this, we selected a sample size of 100 patients.

One hundred consecutive cases in the age group of 1865 years of either sex presenting with a diagnosis of Schizophrenia (F20) and fulfilling inclusion \& exclusion criteria were included after obtaining a written informed consent by purposive random sampling. The sociodemographic and clinical variables were recorded in a proforma designed for the study. Patients were then subjected for anthropometric measurements and laboratory investigations to ascertain for the presence or absence of Metabolic Syndrome as per International Diabetes Federation (IDF) criteria. $^{13}$

\section{Fasting blood sugar kit}

Fasting blood sugar estimation was be done by GOD-PAP method calorimetric determination as described by David BS, $2001 .^{14}$

\section{Lipid profile kit}

Enzymatic determination of cholesterol in HDL fraction was be done by precipitation techniques described by Steele BW et al $1976^{15}$ and Triglycerides by enzymatic method as described by Bucolo G and Harold, 1973. ${ }^{16}$

\section{Sypghmomanometer for measuring blood pressure}

The standard clinic procedure (mercury sphygmomanometer with the Korotkoff's sound technique) was used and the guidelines by American Heart Association Guidelines for InClinic Blood Pressure measurement followed. ${ }^{17}$

\section{Measuring tape for waist circumference}

The waist circumference was measured as per the WHO guidelines. ${ }^{18}$

\section{Body Mass Index (BMI) measurement}

Body Mass Index (BMI) was calculated as the weight in kilograms divided by the square of the height in metres $(\mathrm{kg} / \mathrm{m} 2)$.

\section{Analysis of data}

Data was tabulated and coded. Data was analysed using SPSS package version 20. For categorical variables frequencies and percentages was used. The quantitative variables were analysed using measures of central tendency and dispersion. The Chi Square test was used a test of significance for categorical variables and Independent samples $T$ test was used as test of significance. A p value of less than 0.05 was considered as statistically significant.

\section{Results}

The association of metabolic syndrome in schizophrenia in the current study was $42 \%$ (Table 1). The mean values of all metabolic syndrome parameters were all statistically significant when compared with cases without metabolic syndrome ( $\mathrm{p}=0.001$; Table 2$)$.

Majority of the schizophrenia patients with MetS were older $(59.5 \%$ vs $44.8 \%$; $31-50$ years of age) and females (52.4\% vs $36.2 \%$; $\mathrm{p}=0.107$ ) compared to those without MetS. Most of them in MetS group were married (85.7\% vs 56.9\%; $\mathrm{p}=0.006)$, from urban areas $(45.2 \%$ vs $19 \%$; $=0.005)$, had lower educational qualification $(\mathrm{p}=0.01)$ in comparison to the non-MetS group (Table 3).

The MetS group when matched against the non-MetS group, the former had longer mean duration of schizophrenia $(9.64 \pm 8.1$ years vs $3.76 \pm 2.29$ years; $T$ Value $=5.529$ and $p$ value $=0.001)$, more hospitalizations $(66.7 \%$ vs $53.4 \%$; $\mathrm{p}=0.02$ ) and higher medical comorbidity (diabetes $-7.1 \%$ vs nil, hypertension- $9.5 \%$ vs $1.7 \%$ and hypothyroidism- $-1.1 \%$ vs nil; $\mathrm{p}=0.006$ ). (Table 4)

With respect to psychotropic drugs usage; the use of Olanzapine (69\% vs $46.6 \%$; $\mathrm{p}=0.025$ ), longer duration of treatment with Olanzapine $(26.31 \pm 33.9$ months vs $8.98 \pm$ 12.3; $\mathrm{p}=0.001)$ and Amisulpride $(11.0 \pm 21.68$ months vs 3.48 $\pm 9.9 ; \mathrm{p}=0.022)$ were significantly associated with MetS group than the group without MetS. On the contrary, the nonMetS group had more patients receiving risperidone (58.6\%) than the MetS group (Table 5).

The other variables which were associated with manifestation of metabolic syndrome, yet not significant are: occupation, belonging to a lower socioeconomic status, smoking tobacco and alcohol consumption.

The study also did not find any difference between the two groups with respect to family structure, religion, age at onset of schizophrenia and there was no difference between the two groups with respect to use of Clozapine, Quetiapine, Aripiprazole and Haloperidol.

\section{Discussion}

\section{Prevalence of MetS (Table 1)}

In our study, $42 \%$ of patients suffering from schizophrenia had metabolic syndrome. The prevalence rate found in the 
study was comparable closely with the study by Grover $\mathrm{S}$ et al in 2012, who reported a prevalence of $43.6 \%$ as per the IDF criteria. ${ }^{19}$ Various other authors have reported varied prevalence rates. Subashini R et al reported $34.4 \%$ (using ADA criteria), ${ }^{20} \mathrm{Kagal}$ UA et al reported $35 \%$ (using NCEP ATP III) ${ }^{21}$ Singh $\mathrm{M}$ et al reported $31.66 \%$ (using IDF). ${ }^{22}$ Few studies have reported lower prevalence rates viz, Roshdy $\mathrm{R}$ reported $24.9 \%$ (using IDF), ${ }^{23}$ Sarisoy $\mathrm{G}$ et al reported $27 \%$ (using IDF) ${ }^{24}$ and Verma AK et al reported $28 \%$ (using IDF). ${ }^{25}$ These wide variations could be partly due to diverse diagnostic criteria used for diagnosing MetS and studies being carried out in different set of population in various backgrounds.

\section{Components of MetS: (Table 2)}

In our study all the parameters of MetS was higher in the cases. Forty-four percent of the subjects had abdominal obesity (BMI of $>30$ was present in $16 \%$ of the patients), hypertension was present in $27 \%$, hyperglycemia in $21 \%$, low HDL cholesterol among 53\% and high triglycerides among $71 \%$ of the patients.

The present IDF definition emphasizes on central obesity for the diagnosis of MetS, attributing to its higher correlation with insulin resistance ${ }^{26}$ and authors like Jensen et.al have supported this view. ${ }^{27}$ An effective measure of central obesity is provided by Waist circumference in routine clinical practice. In our study, the mean $( \pm S D)$ waist circumference of the patients without metabolic syndrome was $77.65( \pm 6.2)$ $\mathrm{cms}$ and with metabolic syndrome was $89.4( \pm 4.5) \mathrm{cms}$ which was statistically significant $(\mathrm{p}=0.001$; Table 2$)$. Central obesity is a vital feature of the MetS, and is directly proportional to the waist circumference in majority of the population.

In our study, the mean $( \pm \mathrm{SD})$ fasting triglycerides was $157.6( \pm 55.05) \mathrm{mg} / \mathrm{dl}$ among the patients without MetS and $197.5( \pm 39.8)$ in patients with MetS, which was statistically significant $(\mathrm{p}=0.001)$. Elevated levels of triglycerides are associated with atherosclerosis, even in the absence of hypercholesterolemia and predispose to cardiovascular disease. $^{28}$ This unique constitution, described as "hypertriglyceridemic waist" phenotype by Lemieux et al, ${ }^{29}$ can be a simple bedside screening instrument for recognizing individuals with increased cardio metabolic risk.

In our study, the mean $( \pm \mathrm{SD})$ high density lipoprotein was $44.25( \pm 3.84) \mathrm{mg} / \mathrm{dl}$ among the patients without MetS and $40.37( \pm 6.52) \mathrm{mg} / \mathrm{dl}$ among the patients with MetS where the mean difference was statistically significant $(p=0.001)$. Hansel B et al found that antioxidative activity of small, dense HDL sub fractions of altered chemical composition is impaired in MetS and associated with elevated oxidative stress and insulin resistance. Induction of selective increase in the circulating concentrations of dense HDL sub fractions may represent an innovative therapeutic approach for the attenuation of high cardiovascular risk in MetS. ${ }^{30}$

Our study reported that, the mean fasting blood sugar level in patients without MetS was $89.72( \pm 7.46) \mathrm{mg} / \mathrm{dl}$ and with MetS was $100.21( \pm 15.6) \mathrm{mg} / \mathrm{dl}$, where the mean difference was statistically significant $(\mathrm{p}=0.001)$. Insulin resistance is a hallmark in most of the subjects presenting with MetS. Although controversies exist about its role as an autonomous CVD risk factor, meta-analysis by Ruige JB et al., has revealed a significant association of insulin resistance and incident CVD. ${ }^{31}$

The mean systolic and diastolic BP was statistically significant between the two groups $(\mathrm{p}=0.001)$. Essential hypertension is commonly associated with the other metabolic derangements, particularly it's an important accompaniment with obesity, hyperglycemia and dyslipidemia. ${ }^{32}$

In our study, the mean body mass index among the patients without metabolic syndrome was $25.28( \pm 1.86)$ $\mathrm{kg} / \mathrm{m}^{2}$ and $30.15( \pm 1.51)$ among the patients with metabolic syndrome which was also statistically significant $(\mathrm{p}=0.001)$. Though some criteria use waist circumference (WC) and other use Body mass index (BMI) to estimate the excessive deposition of fat in the body, it has been found that WC and BMI are highly correlated and there's no superiority between the two.

\section{Socio-demographic variables and Metabolic Syndrome (Table 3)}

The mean $( \pm$ SD) age of the study group was $35.68( \pm 11.08)$ years. The mean $( \pm S D)$ age of schizophrenia patients without metabolic syndrome was $31.72( \pm 9.5)$ years while those with metabolic syndrome was $41.14( \pm 10.88)$ years. Majority of the subjects in this study without metabolic syndrome belonged to 21-40 years (70.7\%) and with metabolic syndrome belonged to $31-50$ years (59.5\%). This indicates that MetS was higher in older individuals. Roshdy R found that the frequency of metabolic syndrome increased consistently with age (with MetS $-43.4 \pm 9.5$ vs without MetS

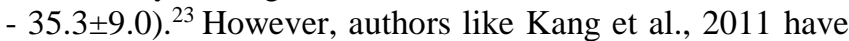
demonstrated this difference of MetS in older age groups in male gender only. ${ }^{33}$

About $52.4 \%$ of cases among the females and $47.6 \%$ among males had MetS in our study. Similar findings of female patients from all culture and traditions being more susceptible to MetS as compared with males has been established in CATIE study. ${ }^{34}$ This finding of gender differences is not uniform across literature and a few studies have reported higher prevalence in males. ${ }^{7}$

In this study $56.9 \%$ of the patients without metabolic syndrome and $85.7 \%$ of the patients with metabolic syndrome were married. This finding of higher prevalence of MetS in people who were married anytime during their lifetime was statistically significant $(\mathrm{p}=0.006)$. Similar reports have been found by Arango $\mathrm{C}$ et al. ${ }^{35}$ and Grover $\mathrm{S}$ et al. $^{36}$

The study, found that the group with MetS had more patients from urban background compared to the group without MetS, which was statistically significant $(p=0.005)$. Grover $\mathrm{S}$ et al found that the risk of MetS in schizophrenia patients of urban background was more than two times that in the patients from rural background $(\mathrm{OR}=2.08)$, which was in line with the findings of the current study. ${ }^{19}$ However, other studies from literature have not replicated similar 
findings. Rapid urbanization, changing dietary trends, increased sedentary occupation and increased perceived stress in an urban environment can all be etiologically related.

Attainment of lower levels of education in the group with metabolic syndrome compared to the group without metabolic syndrome has been found to be statistically significant in the current study $(\mathrm{p}=0.01)$. Sporadic studies have reported association of MetS with higher education level. ${ }^{37,38}$ This could possibly be due to differences in the study population and classification of education into several subgroups, which may not be comparable across studies.

Other socio-demographic parameters did not show much variance between the two groups and there is no decisive evidence regarding the relationship of these parameters with MetS in literature.

\section{Clinical variables and metabolic syndrome (Table 4)}

Majority of the study population $(74 \%)$ had onset of their schizophrenia before 35 years of age. In the group without MetS significant percentage of patients had an early onset (15-25 years of age) compared to the group with MetS (without MetS- $43.1 \%$ vs with MetS- 21.4\%). However, in the following decade (25-35 years of age), there was a reversal of this trend (with MetS- $47.6 \%$ vs without MetS$34.5 \%$ ). According to Meyer and Stahl, the age of metabolic syndrome onset occurs much earlier in individuals with schizophrenia and other severe mental illnesses than in the general population, with high metabolic syndrome prevalence seen among the patients with schizophrenia below the age of thirty. ${ }^{39}$

The mean duration of schizophrenia among patients without metabolic syndrome is 3.76 years and among those with metabolic syndrome is 9.64 years and is statistically significant $(p=0.001)$. While a lengthier duration of illness has been established to be associated with higher prevalence of MetS in some of the studies, ${ }^{19,40-42}$ other studies have shown no association of MetS and duration of illness. ${ }^{43,44} \mathrm{Co}-$ morbid factors like psycho-active substance use, IGF-1 deficiency and inactive lifestyle can also contribute to the advent of metabolic complications in these patients. ${ }^{45}$

The groups differed with respect to number of hospitalizations, which was more in the MetS group and was statistically significant $(\mathrm{p}$ value $=0.020$ ). In the study by Elgamal $\mathrm{M}$ et al, the onset of diabetes mellitus, hypertension and dyslipidemia for most of the cases was during the period of chronic institutionalization, especially at the time of last admission $(n=17,60.71 \% ; n=21,72.41 \%$; and $n=40,81.63 \%$, respectively). ${ }^{46}$ Increased severity, chronicity of illness, multiple psychotropic usage can be confounding factors.

There was no statistically significant difference with respect to use of Nicotine between the two groups. However, a significant proportion of subjects in both the groups had dependence for smoking. (20.7\% of the patients without MetS v/s $23.8 \%$ of the patients with MetS). Tobacco use has been consistently related with an amplified risk of developing MetS. ${ }^{47}$ A national nutrition examination survey in USA reported an increase in risk of development of metabolic syndrome among women (OR, 1.8; 95\% CI: 1.2-2.6) and men (OR, 1.5; 95\% CI: 1.1-2.2) who were current smokers compared with those who never smoked. ${ }^{48}$ Tobacco use is associated with all cascades in the etiopathogenesis of MetS and hence could contribute to development of metabolic syndrome through multiple mechanisms.

About $1.7 \%$ of the cases without metabolic syndrome and $7.1 \%$ of the cases with metabolic syndrome had dependence to alcohol, however it was not statistically significant. It is hypothesized that use of alcohol is a harbinger of hepatic dysregulation leading to disturbances of hepatic gluconeogenesis and oxidation of lactate to pyruvate all of which can lead to development of MetS. ${ }^{49}$

\section{Antipsychotic usage and metabolic syndrome (Table 5)}

Antipsychotic usage is known to increase the prevalence of MetS by about three-fold as compared to the general population. $^{50,51}$ In our study we tried to compare the commonly used antipsychotics between the two groups and understand its outcome.

The use of Olanzapine ( $69 \%$ vs $46.6 \%$; $\mathrm{p}=0.025)$ and mean duration of treatment with Olanzapine $(26.31 \pm 33.9$ months vs $8.98 \pm 12.3$; $\mathrm{p}=0.001$ ) was statistically significant among the patients with and without metabolic syndrome. Similar findings was demonstrated in the CATIE study, wherein patients in the olanzapine group gained the maximum weight (mean weight gain was $0.9 \mathrm{~kg}$ monthly). ${ }^{52}$ Another long term follow-up study of 52-weeks also found the highest weight gain among olanzapine-treated patients. ${ }^{53}$ Olanzapine is the commonest second generation antipsychotic implicated in the causation of MetS. Similar findings are obtained in our study, however being a crosssectional study, its difficult to comment on the exact pathogenesis and presence of other confounding factors has to be considered.

The duration of use of amisulpride was 3.48 months among the patients without metabolic syndrome and 11 months with metabolic syndrome and the difference was statistically significant $(\mathrm{T}$ Value $=2.329, \mathrm{p}$ value $=0.022)$. There are very few data available on the metabolic effects of amisulpride. In general, it is a preferred drug to be used when considering the risk of MetS. The association present in our study need to be interpreted with caution because of the small sample size and cross-sectional nature of the study.

The non-MetS group had more patients receiving risperidone $(58.6 \%)$ than the MetS group. In general, Risperidone is associated with lesser weight gain and has favourable metabolic profile. No significance was obtained on comparison of the two groups with other antipsychotics viz, Clozapine, Quetiapine, Aripiprazole and Haloperidol.

Though various literature suggests about the role of antipsychotics in development of MetS, but controversies and incontinences exist. Some large scale multicentric trials (CLAMORS study), have reported no significance between patients with and without MetS in relation to the mean duration or type of antipsychotic treatment. ${ }^{54}$ 
Table 1: Prevalence of metabolic syndrome in the study population $(\mathrm{N}=100)$

\begin{tabular}{|c|c|}
\hline Metabolic Syndrome & Prevalence (\%) \\
\hline Absent & 58 \\
\hline Present & 42 \\
\hline Total & 100 \\
\hline
\end{tabular}

Table 2: Distribution of the study groups based on the metabolic parameters

\begin{tabular}{|l|c|c|c|c|}
\hline \multicolumn{1}{|c|}{ Metabolic Syndrome Parameters } & \multicolumn{2}{c|}{ Metabolic syndrome } & \multirow{2}{*}{ T value } & \multirow{2}{*}{ p value } \\
\cline { 2 - 5 } & $\begin{array}{c}\text { No } \\
\text { Mean } \pm \text { SD }\end{array}$ & $\begin{array}{c}\text { Yes } \\
\text { Mean } \pm \text { SD }\end{array}$ & & \\
\hline Waist circumference $(\mathrm{cm})$ & $77.65 \pm 6.2$ & $89.4 \pm 4.5$ & 10.4 & $0.001^{* *}$ \\
\hline Fasting Triglycerides $(\mathrm{mg} / \mathrm{dl})$ & $157.6 \pm 55.05$ & $197.5 \pm 39.8$ & 3.996 & $0.001^{* *}$ \\
\hline High density lipoprotein $(\mathrm{mg} / \mathrm{dl})$ & $44.25 \pm 3.84$ & $40.37 \pm 6.52$ & 3.734 & $0.001^{* *}$ \\
\hline Fasting blood sugar $(\mathrm{mg} / \mathrm{dl})$ & $89.72 \pm 7.46$ & $100.21 \pm 15.6$ & 4.47 & $0.001^{* *}$ \\
\hline Blood pressure systolic $(\mathrm{mm}$ of $\mathrm{Hg})$ & $117.93 \pm 5.21$ & $126.14 \pm 8.52$ & 5.961 & $0.001^{* *}$ \\
\hline Blood pressure diastolic $(\mathrm{mm}$ of $\mathrm{Hg})$ & $77.24 \pm 4.51$ & $81.78 \pm 5.8$ & 4.397 & $0.001^{* *}$ \\
\hline Body mass index $\left(\mathrm{kg} / \mathrm{m}^{2}\right)$ & $25.28 \pm 1.86$ & $30.15 \pm 1.51$ & 13.976 & $0.001^{* *}$ \\
\hline
\end{tabular}

Table 3: Socio-demographic variables and metabolic syndrome $(\mathrm{N}=100)$

\begin{tabular}{|c|c|c|c|c|}
\hline \multirow{2}{*}{ Socio-demographic Variable } & \multicolumn{2}{|c|}{ Metabolic Syndrome } & \multirow[b]{2}{*}{$\begin{array}{l}\text { Total } \\
(\mathbf{N \%})\end{array}$} & \multirow[b]{2}{*}{$\begin{array}{c}\text { Test } \\
\text { p value }\end{array}$} \\
\hline & No $(n \%)$ & Yes $(\mathrm{n} \%)$ & & \\
\hline \multicolumn{5}{|l|}{ Age group } \\
\hline$<20$ years & $7(12.1)$ & 0 & $7(7.0)$ & \\
\hline $21-30$ years & $23(39.7)$ & $7(16.7)$ & $30(30.0)$ & \\
\hline $31-40$ years & $18(31.0)$ & $16(38.1)$ & $34(34.0)$ & \\
\hline $41-50$ years & $8(13.8)$ & $9(21.4)$ & $17(17.0)$ & \\
\hline $51-60$ years & $1(1.7)$ & $8(19.0)$ & $9(9.0)$ & \\
\hline$>60$ years & $1(1.7)$ & $2(4.8)$ & $3(3.0)$ & \\
\hline Total & $58(100)$ & $42(100)$ & $100(100)$ & \\
\hline Mean \pm SD & $31.72 \pm 9.5$ & $41.14 \pm 10.88$ & $35.68 \pm 11.08$ & \\
\hline \multicolumn{5}{|l|}{ Gender } \\
\hline Male & $37(63.8)$ & $20(47.6)$ & $57(57.0)$ & \multirow{3}{*}{$\begin{array}{c}\begin{array}{c}\chi 2 \text { Value }=2.6 \\
d f=1\end{array} \\
\text { p value }=0.107\end{array}$} \\
\hline Female & $21(36.2)$ & $22(52.4)$ & $43(43.0)$ & \\
\hline Total & $58(100)$ & $42(100)$ & $100(100)$ & \\
\hline \multicolumn{5}{|l|}{ Marital Status } \\
\hline Married & $33(56.9)$ & $36(85.7)$ & $69(69.0)$ & \multirow{4}{*}{$\begin{array}{c}\chi^{2} \text { Value }=10.282 \\
\mathrm{df}=2 \\
\text { p value }=\mathbf{0 . 0 0 6} * \text { Sig }\end{array}$} \\
\hline Unmarried & $24(41.4)$ & $5(11.9)$ & $29(29.0)$ & \\
\hline Divorced & $1(1.7)$ & $1(2.4)$ & $2(2.0)$ & \\
\hline Total & $58(100)$ & $42(100)$ & $100(100)$ & \\
\hline \multicolumn{5}{|l|}{ Educational Status } \\
\hline Illiterate & 0 & $4(9.5)$ & $4(4.0)$ & \multirow{7}{*}{$\begin{array}{c}\chi^{2} \text { Value }=15.052 \\
\mathrm{df}=5 \\
\mathrm{p} \text { value }=\mathbf{0 . 0 1} *\end{array}$} \\
\hline Primary school certificate & $6(10.3)$ & $10(23.8)$ & $16(16.0)$ & \\
\hline Middle school certificate & $20(34.5)$ & $6(14.3)$ & $26(26.0)$ & \\
\hline High school certificate & $22(37.9)$ & $10(23.8)$ & $32(32.0)$ & \\
\hline $\begin{array}{c}\text { Intermediate or post high } \\
\text { school diploma }\end{array}$ & $6(10.3)$ & $7(16.7)$ & $13(13.0)$ & \\
\hline Graduate or post graduate & $4(6.9)$ & $5(11.9)$ & $9(9.0)$ & \\
\hline Total & $58(100)$ & $42(100)$ & $100(100)$ & \\
\hline \multicolumn{5}{|l|}{ Family Type } \\
\hline Nuclear & $47(81.0)$ & $27(64.3)$ & $74(74.0)$ & \multirow{3}{*}{$\begin{array}{c}\chi^{2} \text { Value }=3.552 \\
\mathrm{df}=1 \\
\mathrm{p} \text { value }=0.059\end{array}$} \\
\hline Joint & $11(19.0)$ & $15(35.7)$ & $26(26.0)$ & \\
\hline Total & $58(100)$ & $42(100)$ & $100(100)$ & \\
\hline \multicolumn{5}{|l|}{ Occupation } \\
\hline Unemployed & 34 (58.6) & $27(64.3)$ & $61(61.0)$ & \multirow{4}{*}{$\begin{array}{c}\chi^{2} \text { Value }=2.744 \\
d f=6 \\
\text { p value }=0.84\end{array}$} \\
\hline Unskilled worker & $6(10.3)$ & $4(9.5)$ & $10(10.0)$ & \\
\hline Semi-skilled worker & $8(13.8)$ & $3(7.1)$ & $11(11.0)$ & \\
\hline Skilled worker & $5(8.6)$ & $6(14.3)$ & $11(11.0)$ & \\
\hline
\end{tabular}




\begin{tabular}{|c|c|c|c|c|}
\hline Clerical, shop owner, Farmer & $1(1.7)$ & 0 & $1(1.0)$ & \\
\hline Semi profession & $2(3.4)$ & $1(2.4)$ & $3(3.0)$ & \\
\hline Profession & $2(3.4)$ & $1(2.4)$ & $3(3.0)$ & \\
\hline Total & $58(100)$ & $42(100)$ & $100(100)$ & \\
\hline \multicolumn{5}{|l|}{ Residence } \\
\hline Rural & 47 (81.0) & $23(54.8)$ & $70(70.0)$ & \multirow{3}{*}{$\begin{array}{c}\chi 2 \text { Value }=8.007 \\
d f=1 \\
p \text { value }=0.005^{*}\end{array}$} \\
\hline Urban & $11(19.0)$ & 19 (45.2) & $30(30.0)$ & \\
\hline Total & $58(100)$ & $42(100)$ & $100(100)$ & \\
\hline \multicolumn{5}{|l|}{ SES } \\
\hline Upper middle & $7(12.1)$ & $5(11.9)$ & $12(12.0)$ & \multirow{5}{*}{$\begin{array}{c}\chi^{2} \text { Value }=0.509 \\
\mathrm{df}=3 \\
\mathrm{p} \text { value }=0.917\end{array}$} \\
\hline Lower middle & $43(74.1)$ & $29(69.0)$ & $72(72.0)$ & \\
\hline Upper lower & $7(12.1)$ & $7(16.7)$ & $14(14.0)$ & \\
\hline Lower & $1(1.7)$ & $1(2.4)$ & $2(2.0)$ & \\
\hline Total & $58(100)$ & $42(100)$ & $100(100)$ & \\
\hline
\end{tabular}

Table 4: Clinical variables and metabolic syndrome $(\mathrm{N}=100)$

\begin{tabular}{|c|c|c|c|c|}
\hline \multirow{2}{*}{ Clinical Variable } & \multicolumn{2}{|c|}{ Metabolic Syndrome } & \multirow{2}{*}{$\begin{array}{l}\text { Total } \\
\text { (N\%) }\end{array}$} & \multirow{2}{*}{$\begin{array}{c}\text { Test } \\
\text { p value }\end{array}$} \\
\hline & No $(\mathbf{n \%})$ & Yes $(\mathrm{n} \%)$ & & \\
\hline \multicolumn{5}{|c|}{ Age at onset of schizophrenia } \\
\hline 15 to $\leq 25$ years & $25(43.1)$ & $9(21.4)$ & $34(34.0)$ & \multirow{6}{*}{$\begin{array}{c}\chi^{2} \text { Value }=5.307 \\
\mathrm{df}=4 \\
\mathrm{p} \text { value }=0.257\end{array}$} \\
\hline 25 to $\leq 35$ years & $20(34.5)$ & $20(47.6)$ & $40(40.0)$ & \\
\hline 35 to $\leq 45$ years & $8(13.8)$ & $9(21.4)$ & $17(17.0)$ & \\
\hline 45 to $\leq 55$ years & $4(6.9)$ & $3(7.1)$ & $7(7.0)$ & \\
\hline 55 to $\leq 65$ years & $1(1.7)$ & $1(2.4)$ & $2(2.0)$ & \\
\hline Total & $58(100)$ & $42(100)$ & $100(100)$ & \\
\hline \multicolumn{5}{|c|}{ Total duration of schizophrenia } \\
\hline 0 to $<5$ years & $44(75.9)$ & $15(35.7)$ & $59(59.0)$ & \multirow{6}{*}{$\begin{array}{c}\chi^{2} \text { Value }=28.458 \\
\mathrm{df}=4 \\
\text { p value }=\mathbf{0 . 0 0 1} * *\end{array}$} \\
\hline 5 to 10 years & $13(22.4)$ & $9(21.4)$ & $22(22.0)$ & \\
\hline 10 to 15 years & $1(1.7)$ & $12(28.6)$ & $13(13.0)$ & \\
\hline 15 to 25 years & 0 & $3(7.1)$ & $3(3.0)$ & \\
\hline$>25$ years & 0 & $3(7.1)$ & $3(3.0)$ & \\
\hline Total & $58(100)$ & $42(100)$ & $100(100)$ & \\
\hline \multicolumn{5}{|c|}{ Total duration of schizophrenia (number of years) } \\
\hline Mean \pm SD & $3.76 \pm 2.29$ & $9.64 \pm 8.1$ & & $\begin{array}{c}\mathrm{T} \text { Value }=5.529 \\
\mathrm{p} \text { value }=\mathbf{0 . 0 0 1}\end{array}$ \\
\hline \multicolumn{5}{|c|}{ Number of hospitalizations } \\
\hline 0 & 27 (46.6) & $14(33.3)$ & $41(41.0)$ & \multirow{4}{*}{$\begin{array}{c}\chi^{2} \text { Value }=7.851 \\
\mathrm{df}=2 \\
\text { p value }=\mathbf{0 . 0 2 0} *\end{array}$} \\
\hline 1 to 5 & $30(51.7)$ & $21(50.0)$ & $51(51.0)$ & \\
\hline 6 to 10 & $1(1.7)$ & $7(16.7)$ & $8(8.0)$ & \\
\hline Total & $58(100)$ & $42(100)$ & $100(100)$ & \\
\hline \multicolumn{5}{|c|}{ Co-morbid medical conditions } \\
\hline Nil & $57(98.3)$ & $32(76.2)$ & $89(89.0)$ & \multirow{5}{*}{$\begin{aligned} \chi^{2} \text { Value } & =12.585 \\
d f & =3 \\
\text { p value } & =0.006 *\end{aligned}$} \\
\hline Diabetes & 0 & $3(7.1)$ & $3(3.0)$ & \\
\hline Hypertension & $1(1.7)$ & $4(9.5)$ & $5(5.0)$ & \\
\hline Hypothyroid & 0 & $3(7.1)$ & $3(3.0)$ & \\
\hline Total & $58(100)$ & $42(100)$ & $100(100)$ & \\
\hline \multicolumn{5}{|l|}{ Cigarette smoking } \\
\hline Non smoker & $46(79.3)$ & $32(76.2)$ & $78(78.0)$ & \multirow{3}{*}{$\begin{array}{c}\chi^{2} \text { Value }=0.138 \\
\mathrm{df}=1 \\
\mathrm{p} \text { value }=0.71\end{array}$} \\
\hline Dependence & $12(20.7)$ & $10(23.8)$ & $22(22.0)$ & \\
\hline Total & $58(100)$ & $42(100)$ & $100(100)$ & \\
\hline \multicolumn{5}{|l|}{ Alcohol consumption } \\
\hline Non-alcoholic & $53(91.4)$ & $37(88.1)$ & $90(90.0)$ & \multirow{4}{*}{$\begin{array}{c}\chi^{2} \text { Value }=2.002 \\
\mathrm{df}=2 \\
\text { p value }=0.367\end{array}$} \\
\hline Dependence & $1(1.7)$ & $3(7.1)$ & $4(24.0)$ & \\
\hline Occasional use & $4(6.9)$ & $2(4.8)$ & $6(6.0)$ & \\
\hline Total & $58(100)$ & $42(100)$ & $100(100)$ & \\
\hline
\end{tabular}


Table 5: Antipsychotic usage and metabolic syndrome $(\mathrm{N}=100)$

\begin{tabular}{|c|c|c|c|c|}
\hline \multirow[t]{2}{*}{ Clinical Variable } & \multicolumn{2}{|c|}{ Metabolic Syndrome } & \multirow{2}{*}{$\begin{array}{l}\text { Total } \\
(\mathrm{N} \%)\end{array}$} & \multirow{2}{*}{$\begin{array}{c}\text { Test } \\
\text { p value }\end{array}$} \\
\hline & No $(\mathrm{n} \%)$ & Yes $(\mathrm{n} \%)$ & & \\
\hline \multicolumn{5}{|l|}{ Olanzapine } \\
\hline Nil & $31(53.4)$ & $13(31.0)$ & $44(44.0)$ & \multirow{3}{*}{$\begin{array}{c}\chi^{2} \text { Value }=5.003 \\
\mathrm{df}=1 \\
\mathrm{p} \text { value }=\mathbf{0 . 0 2 5} *\end{array}$} \\
\hline Yes & $27(46.6)$ & $29(69.0)$ & $56(56.0)$ & \\
\hline Total & $58(100)$ & $42(100)$ & $100(100)$ & \\
\hline $\begin{array}{c}\text { Mean duration of use } \pm \\
\text { SD }\end{array}$ & $8.98 \pm 12.3$ & $26.31 \pm 33.9$ & & $\begin{array}{c}\mathrm{T} \text { Value }=3.586 \\
\mathrm{p} \text { value }=\mathbf{0 . 0 0 1} * *\end{array}$ \\
\hline \multicolumn{5}{|l|}{ Risperidone } \\
\hline Not used & $24(41.4)$ & $23(54.8)$ & $47(47.0)$ & \multirow{3}{*}{$\begin{array}{c}\chi^{2} \text { Value }=1.751 \\
\mathrm{df}=1 \\
\mathrm{p} \text { value }=0.186\end{array}$} \\
\hline Yes & $34(58.6)$ & $19(45.2)$ & $53(53.0)$ & \\
\hline Total & $58(100)$ & $42(100)$ & $100(100)$ & \\
\hline $\begin{array}{c}\text { Mean duration of use } \pm \\
\text { SD }\end{array}$ & $14.71 \pm 15.62$ & $16.43 \pm 23.33$ & & $\begin{array}{l}\mathrm{T} \text { Value }=0.442 \\
\mathrm{p} \text { value }=0.659\end{array}$ \\
\hline \multicolumn{5}{|l|}{ Amisulpride } \\
\hline Not use & $48(82.8)$ & $31(73.8)$ & $79(79.0)$ & \multirow{3}{*}{$\begin{array}{c}\chi^{2} \text { Value }=1.176 \\
\mathrm{df}=1 \\
\mathrm{p} \text { value }=0.278\end{array}$} \\
\hline Yes & $10(17.2)$ & $11(26.2)$ & $21(21.0)$ & \\
\hline Total & $58(100)$ & $42(100)$ & $100(100)$ & \\
\hline $\begin{array}{c}\text { Mean duration of use } \pm \\
\text { SD }\end{array}$ & $3.48 \pm 9.9$ & $11.0 \pm 21.68$ & & $\begin{array}{c}\mathrm{T} \text { Value }=2.329 \\
\mathrm{p} \text { value }=\mathbf{0 . 0 2 2} *\end{array}$ \\
\hline \multicolumn{5}{|l|}{ Clozapine } \\
\hline Not used & $52(89.7)$ & $37(88.1)$ & $89(89.0)$ & \multirow{3}{*}{$\begin{array}{c}\chi^{2} \text { Value }=0.061 \\
\mathrm{df}=1 \\
\mathrm{p} \text { value }=0.806\end{array}$} \\
\hline Yes & $6(10.3)$ & $5(11.9)$ & $11(11.0)$ & \\
\hline Total & $58(100)$ & $42(100)$ & $100(100)$ & \\
\hline $\begin{array}{c}\text { Mean duration of use } \pm \\
\text { SD }\end{array}$ & $2.88 \pm 9.6$ & $3.05 \pm 9.5$ & & $\begin{array}{l}\text { T Value }=0.087 \\
\mathrm{p} \text { value }=0.931\end{array}$ \\
\hline \multicolumn{5}{|l|}{ Quetiapine } \\
\hline Nil & $56(96.6)$ & $39(92.9)$ & $95(95.0)$ & \multirow{3}{*}{$\begin{array}{c}\chi^{2} \text { Value }=0.7 \\
\mathrm{df}=1 \\
\mathrm{p} \text { value }=0.403\end{array}$} \\
\hline Yes & $2(3.4)$ & $3(7.1)$ & $5(5.0)$ & \\
\hline Total & $58(100)$ & $42(100)$ & $100(100)$ & \\
\hline $\begin{array}{c}\text { Mean duration of use } \pm \\
\text { SD }\end{array}$ & $0.9 \pm 5.14$ & $3.14 \pm 13.27$ & & $\begin{array}{l}\mathrm{T} \text { Value }=1.175 \\
\mathrm{p} \text { value }=0.243\end{array}$ \\
\hline \multicolumn{5}{|l|}{ Aripiprazole } \\
\hline Nil & $46(79.3)$ & $35(83.3)$ & $81(81.0)$ & \multirow{3}{*}{$\begin{array}{c}\chi^{2} \text { Value }=0.256 \\
\mathrm{df}=1 \\
\mathrm{p} \text { value }=0.613\end{array}$} \\
\hline Yes & $12(20.7)$ & $7(16.7)$ & $19(19.0)$ & \\
\hline Total & $58(100)$ & $42(100)$ & $100(100)$ & \\
\hline $\begin{array}{c}\text { Mean duration of use } \pm \\
\text { SD }\end{array}$ & $5.07 \pm 10.83$ & $3.76 \pm 9.51$ & & $\begin{array}{l}\mathrm{T} \text { Value }=0.627 \\
\mathrm{p} \text { value }=0.532\end{array}$ \\
\hline \multicolumn{5}{|l|}{ Haloperidol } \\
\hline Not used & $53(91.4)$ & $41(97.6)$ & $94(94.0)$ & \multirow{3}{*}{$\begin{array}{c}\chi^{2} \text { Value }=1.682 \\
\mathrm{df}=1 \\
\mathrm{p} \text { value }=0.195\end{array}$} \\
\hline Yes & $5(8.6)$ & $1(2.4)$ & $6(6.0)$ & \\
\hline Total & $58(100)$ & $42(100)$ & $100(100)$ & \\
\hline $\begin{array}{c}\text { Mean duration of use } \pm \\
\text { SD }\end{array}$ & $1.10 \pm 4.14$ & $0.57 \pm 3.7$ & & $\begin{array}{l}\mathrm{T} \text { Value }=0.662 \\
\mathrm{p} \text { value }=0.509\end{array}$ \\
\hline
\end{tabular}

p Value: *Significant, ** Highly Significant

\section{Conclusion}

The study shows that the association of metabolic syndrome in schizophrenia patients is significantly higher and thereby underlines the importance of early detection and treatment of both the disorders simultaneously. Several sociodemographic and clinical variables (including the use of psychotropics) are important predictors of MetS and play a pivotal role in the morbidity and mortality of schizophrenia. Early recognition and evaluation of these markers can prevent/protract the onset of MetS and prevent further complications.

\section{Source of Funding}

None.

\section{Conflict of Interest}

Nil. 


\section{References}

1. Schultz SH, North SW, Shields CG. Schizophrenia: a review. Am Fam Physician. 2007;75(12):1821-9.

2. Newman SC, Bland RC. Mortality in a cohort of patients with schizophrenia: a record linkage study. Can J Psychiatry. 1991:36(4):239-45.

3. Ringen PA, Engh JA, Birkenaes AB, Dieset I, Andreassen OA. Increased mortality in schizophrenia due to cardiovascular disease - a non-systematic review of epidemiology, possible causes, and interventions. Front Psychiatry. 2014;5:137.

4. Saha S, Chant D, McGrath J. A systematic review of mortality in schizophrenia: is the differential mortality gap worsening over time? Arch Gen Psychiatry. 2007;64(10):1123-31.

5. Laursen TM, Munk-Olsen T, Vestergaard M. Life expectancy and cardiovascular mortality in persons with schizophrenia. Curr Opin Psychiatry. 2012;25(2):83-8.

6. Osby U, Correia N, Brandt L, Ekbom A, Sparén P. Mortality and causes of death in schizophrenia in Stockholm county, Sweden. Schizophr Res. 2000;45(1-2):21-8.

7. Malhotra N, Grover S, Chakrabarti S, Kulhara P. Metabolic syndrome in schizophrenia. Indian J Psychol Med. 2013;35(3):227-40.

8. Papanastasiou E. The prevalence and mechanisms of metabolic syndrome in schizophrenia: a review. Ther $A d v$ Psychopharmacol. 2013;3(1):33-51.

9. Kaur, J. A comprehensive review on metabolic syndrome. Cardiol Res Pract. 2014;11:1-21.

10. Edwardson CL, Gorely T, Davies MJ. Association of sedentary behaviour with metabolic syndrome: A meta-analysis. PLoS One. 2012;7(4):e34916.

11. Capasso RM, Lineberry TW, Bostwick JM, Decker PA, St Sauver J. Mortality in schizophrenia and schizoaffective disorder: An Olmsted County, Minnesota cohort: 1950-2005. Schizophr Res. 2008;98:287-94.

12. Thakore JH, Mann JN, Vlahos I, Martin A, Reznek R. Increased visceral fat distribution in drug-naive and drug-free patients with schizophrenia. Int J Obes Relat Metab Disord. 2002; $26: 137-41$

13. The IDF consensus worldwide definition of the metabolic syndrome. [Last accessed on 2020 March 03]. Available from: https://www.idf.org/e-library/consensus-statements/60idfconsensus-worldwide-definitionof-the-metabolicsyndrome.html

14. David BS: Carbohydrate, Teitz Fundamental of clinical chemistry, Carl A Burtis and Edward R Ashwood, 5th edition. New Delhi: Harcourt (India) Private limited. 2001:427-61.

15. Steele BW, Donald FK, Magnel MA, Thomas PB, Kanta K, Mary ED: Enzymatic determination of cholesterol in high density lipoprotein fractions prepared by precipitation techniques. Clin Chem.1976;22:98-101.

16. Bucolo $\mathrm{G}$ and Harold D: Quantitaive determination of serum triglycerides by the use of enzymes. Clin Chem. 1973;15:47681.

17. Smith L. New AHA Recommendations for blood pressure measurement. Am Fam Physician. 2005;72(7):1391-8.

18. Waist Circumference and Waist-Hip Ratio: Report of a WHO Expert Consultation. Geneva, 8-11 December 2008.

19. Grover S, Aggarwal M, Dutt A, Chakrabarti S, Avasthi A, Kulhara P, et al. Prevalence of metabolic syndrome in patients with schizophrenia in India. Psychiatry Res. 2012;200:1035-7.

20. Subashini R, Deepa M, Padmavati R, Thara R, Mohan V. Prevalence of diabetes, obesity, and metabolic syndrome in subjects with and without schizophrenia (CURES-104). $J$ Postgrad Med. 2011;57:272-7.

21. Kagal UA, Torgal SS, Patil NM, Malleshappa A. Prevalence of the metabolic syndrome in schizophrenic patients receiving second-generation antipsychotic agents--a cross-sectional study. J Pharm Pract. 2012;25:368-73.
22. Singh M, Swami MK, Singh L, Solanki RK. A study of metabolic syndrome in chronic institutionalized patients with schizophrenia. IAIM. 2016;3(3):99-105.

23. Roshdy R. Prevalence of metabolic syndrome in patients with schizophrenia. Middle East Curr Psychiatry. 2011;18:109-17.

24. Sarisoy G, Boke O, Ozturk A, Akkaya D, Pazvantoglu O, Sahin AR, The correlation between incidence of metabolic syndrome and socio demographic and clinical characteristics in schizophrenia patients. J Psychiatry Neurol Sci. 2013;26:26775.

25. Verma AK, Bajaj S, Verma S, Varma A, Meena LP. Study of the association of metabolic syndrome with schizophrenia in North Eastern part of India. Int J Med Sci Public Health. 2013;2:583-7.

26. Carr DB, Utzschneider KM, Hull RL, Kodama K, Retzlaff BM, Brunzell JD, et al. Intra-Abdominal Fat Is a Major Determinant of the National Cholesterol Education Program Adult Treatment Panel III Criteria for the Metabolic Syndrome. Diabetes. 2004; 53: 2087-94.

27. Jensen MD, Haymond MW, Rizza RA, Cryer PE, Miles JM. Influence of body fat distribution on free fatty acid metabolism in obesity. J Clin Invest. 1989;83(4):1168-73.

28. Berglund L, Brunzell JD, Goldberg AC. Evaluation and treatment of hypertriglyceridemia: an endocrine society clinical practice guideline. J Clin Endocrinol Metab. 2012;97(9):2969-89.

29. Lemieux I, Pascot A, Couillard C. Hypertriglyceridemic waist: A marker of the atherogenic metabolic triad (hyperinsulinemia, hyperapolipoprotein B, small, dense LDL) in men? Circ. 2000;102:179-84.

30. Hansel B, Giral P, Nobecourt E, Chantepie S, Bruckert E, Chapman MJ, Kontush A. Metabolic syndrome is associated with elevated oxidative stress and dysfunctional dense highdensity lipoprotein particles displaying impaired antioxidative activity. J Clin Endocrinol Metab. 2004;89(10):4963-11.

31. Ruige JB, Assendelft WJJ, Dekker JM, Kostense PJ, Heine RJ, Bouter LM. Insulin and Risk of Cardiovascular Disease: A Meta-Analysis. Circ. 1998;97:996-1001.

32. Ferrannini E, Natali A. Essential hypertension, metabolic disorders, and insulin resistance. Am Heart $J$. 1991;121(4):1274-82.

33. Kang SH, Lee JI, Chang AK, Joo YH, Kim CY, Kim SY. Genetic polymorphisms in the HTR2C and peroxisome proliferator-activated receptors are not associated with metabolic syndrome in patients with schizophrenia taking clozapine. Psychiatry Investig. 2011;8:262-8.

34. McEvoy JP, Meyer JM, Goff DC, Nasrallah HA, Davis SM, Sullivan L, et al. Prevalence of the metabolic syndrome in patients with schizophrenia: Baseline results from the Clinical Antipsychotic Trials of Intervention Effectiveness (CATIE) schizophrenia trial and comparison with national estimates from NHANES III. Schizophr Res. 2005;80:19-32.

35. Arango C, Bobes J, Aranda P, Carmena R, Garcia-Garcia M, Rejas J CLAMORS Study Collaborative Group. A comparison of schizophrenia outpatients treated with antipsychotics with and without metabolic syndrome: Findings from the CLAMORS study. Schizophr Res. 2008;104:1-12.

36. Grover S, Nebhinani N, Chakrabarti S, Avasthi A, Kulhara P, Basu D, et al. Comparative study of prevalence of metabolic syndrome in bipolar disorder and schizophrenia from North India. Nord J Psychiatry. 2013.

37. Grover S, Nebhinani N, Chakrabarti S, Avasthi A, Kulhara P Metabolic syndrome among patients receiving clozapine: A preliminary estimate. Indian J Pharmacol. 2011;43:591-5.

38. Pallava A, Chadda RK, Sood M, Lakshmy R. Metabolic syndrome in schizophrenia: A comparative study of antipsychotic-free/naïve and antipsychotic-treated patients from India. Nord J Psychiatry. 2012;66:215-21. 
39. Meyer JM, Stahl SM. The metabolic syndrome and schizophrenia. Acta Psychiatrica Scand. 2008:119:4-14.

40. Cerit C, Özten E, Yildiz M. The prevalence of metabolic syndrome and related factors in patients with schizophrenia. Turk Psikiyatri Derg. 2008;19:124-32.

41. Güveli H, Cem IM, Yener F, Karamustafalioğlu N, Ipekçioğlu $\mathrm{D}$, Abanoz Z. The frequency of metabolic syndrome in schizophrenia patients using antipsychotic medication and related factors. Yeni Symp. 2011;49:67-76.

42. Kim CH, Nam YY, Ahn CW. Clinical correlates of metabolic syndrome in patients with chronic schizophrenia. Schiophr Res. 2008;102:242-3.

43. Kaya MC, Virit O, Altindag A, Selek S, Bülbül F, Bulut M, et al. Prevalence of metabolic syndrome, characteristics of metabolic syndrome and relationship with the antipsychotics used in schizophrenia. Nöropsikiyatri Arşivi. 2009;46:13.

44. Yoon BH, Bae A, Bahk WM. Prevalence and characteristics of metabolic syndrome in schizophrenic inpatients. Schizophr Res. 2008;102:244.

45. Chadda RK, Ramshankar P, Deb KS, Sood M, Chadda RK, Ramshankar P, et al. Metabolic syndrome in schizophrenia: Differences between antipsychotic-naïve and treated patients. $J$ Pharmacol Pharmacother. 2013;4:176-86.

46. Elgamal M, Eltayebani M, Fathy S, Metabolic syndrome and type 2 diabetes in chronic institutionalized patients with schizophrenia. Egypt Psychiatry. 2012;33:171-80.

47. Miyatake N, Wada J, Kawasaki Y, Nishii K, Makino H, Numata T. Relationship between metabolic syndrome and cigarette smoking in the Japanese population. Intern Med. 2006;45:1039-43.

48. Park YW, Zhu S, Palaniappan L, Heshka S, Carnethon MR, Heymsfield SB. The metabolic syndrome: prevalence and associated risk factor findings in the US population from the
Third National Health and Nutrition Examination Survey, 1988-1994. Arch Intern Med. 2003;163:427-36.

49. Jelski W, Szmitkowski M. Effect of ethanol on metabolic syndrome. Pol Arch Med Wewn. 2007;117:306-11.

50. Kato MM, Currier MB, Gomez CM, Hall L, Gonzalez-Blanco M. Prevalence of Metabolic Syndrome in Hispanic and NonHispanic patients with schizophrenia. Prim Care Companion J Clin Psychiatry. 2004;6:74-7.

51. Tirupati $S$, Chua LE. Obesity and metabolic syndrome in a psychiatric rehabilitation service. Aust N Z J Psychiatry. 2007;41:606-10.

52. Lieberman JA, Stroup TS, McEvoy JP, Swartz MS, Rosenheck RA, Perkins DO, et al. Effectiveness of antipsychotic drugs in patients with chronic schizophrenia. $N$ Engl J Med. 2005;353:1209-23.

53. Patel JK, Buckley PF, Woolson S, Hamer RM, McEvoy JP, Perkins DO, et al. Metabolic profiles of second-generation antipsychotics in early psychosis: Findings from the CAFE study. Schizophr Res. 2009;111:9-16.

54. Arango C, Bobes J, Aranda P, Carmena R, Garcia-Garcia M, Rejas J, et al. A comparison of schizophrenia outpatients treated with antipsychotics with and without metabolic syndrome: Findings from the CLAMORS study. Schizophr Res. 2008;104:1-12.

How to cite this article: Raj R, Sattar FA, Kumar KK. Metabolic syndrome in patients with Schizophrenia: Relationship with socio-demographic \& clinical variables. Telangana J Psychiatry. 2020;6(1):25-33. 